Volume 3, Issue 1 (Winter 2011)

\title{
Envisioning Netherlandish Unity: Claes Visscher's 1612 Copies of the Small Landscape Prints
}

Alexandra Onuf

Recommended Citation:

Alexandra Onuf, "Envisioning Netherlandish Unity: Claes Visscher's 1612 Copies of the Small Landscape Prints," JHNA 3:1 (Winter 2011), DOI: 10.5092/jhna.2011.3.1.4

Available at https://jhna.org/articles/envisioning-netherlandish-unity-claes-visscher-1612-copies-small-landscape-prints/

Published by Historians of Netherlandish Art: https://hnanews.org/

Republication Guidelines: https://jhna.org/republication-guidelines/

Notes: This PDF is provided for reference purposes only and may not contain all the functionality or features of the original, online publication. This is a revised PDF that may contain different page numbers from the previous version. Use electronic searching to locate passages. This PDF provides paragraph numbers as well as page numbers for citation purposes.

ISSN: 1949-9833 


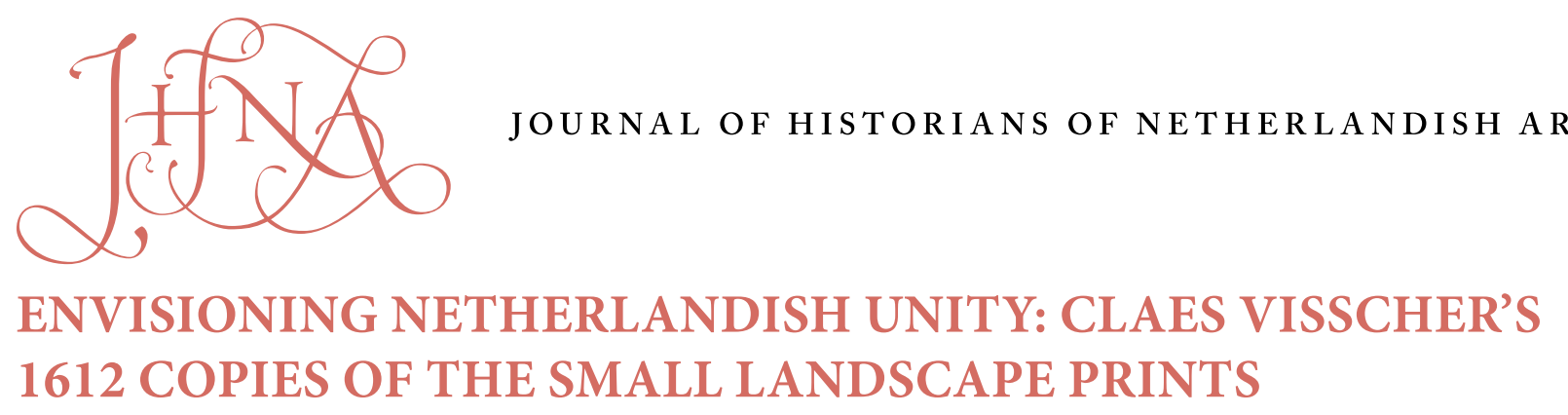

Alexandra Onuf

Scholars have long recognized the formal significance of Claes Jansz. Visscher's 1612 copies of the Small Landscape prints for the development of seventeenth-century Dutch landscapes. The prints, which were originally published in Antwerp in the mid-sixteenth century, represent the rural terrain of Brabant with a direct naturalism and topographic specificity that would later become a hallmark of Dutch Golden Age landscape prints and paintings. This article focuses on the content of the series and attempts to understand the Dutch market and appreciation for views of Brabant in the early seventeenth century. Published in the early years of the Twelve Years'Truce, likely with the vast émigré population of Southern Netherlanders in mind, the prints visually restore Brabant to its pre-Revolt past of peace and prosperity at the same time as they stimulate hope for a reunification of this lost southern province into a new United Netherlands.10.5092/jhna.2011.3.1.4

laes Jansz. Visscher has long been acknowledged as a pivotal figure in the early development of seventeenth-century Dutch landscapes. Soon after setting up shop on the Kalverstraat in Amsterdam in 1611, Visscher began issuing a remarkable number of landscape prints that offered realistic views of the local Dutch countryside, quickly establishing himself as the leading publisher of Dutch landscape prints in Amsterdam. ${ }^{1}$ However, many of the earliest of these prints were not original series, nor did they depict Dutch locales. Instead, Visscher's specialization in landscapes first took shape through a campaign to republish Flemish landscapes from the sixteenth century.

At the center of what we might call this "Flemish revival" stands Visscher's copied set of the Small Landscapes, views of the Brabantine countryside and villages that were originally published in two sets by Hieronymus Cock in Antwerp in 1559 and 1561 (figs.1-7). ${ }^{2}$ Unable to acquire the original plates for the series, which remained in Antwerp in the possession of the Galle printing dynasty, Visscher did the next best thing, copying twenty-six of the original forty-four views, which he published as a set in 1612, under the title Regiunculae, et Villae Aliquot Ducatus Brabantiae, with a newly devised title page, which will be discussed below. The views in the original Small Landscape series appear to depict particular places and to concentrate their visual focus on the local terrain itself. The two title pages that Cock issued with his original series assert that the views were in fact drawn "naer d'leven" and "ad vivum," respectively - that is to say, from life (fig. 1). ${ }^{3}$ Cock's Small Landscapes include only scant staffage, and the few figures that are included appear 


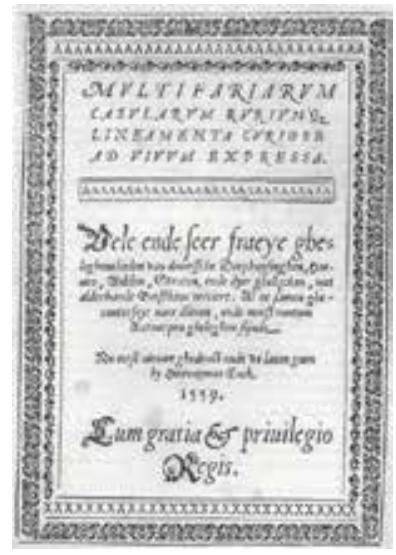

Fig. 1 Title page, from"Multifariarum Casularum Ruriumq ..., "the first set of the Small Landscapes, published by Hieronymus Cock (Antwerp, 1559)

incidental and never distract from the primary focus on the locales themselves. This same sense of topographic specificity is communicated in Visscher's copies. There can be no doubt that these small, humble views of country villages and rural farms, half a century old by the time Visscher encountered them, spurred the young printmaker and publisher to represent his native Dutch terrain with a similar simplicity and specificity and, in so doing, helped to usher in a new mode of naturalistic Dutch landscape imagery. ${ }^{4}$

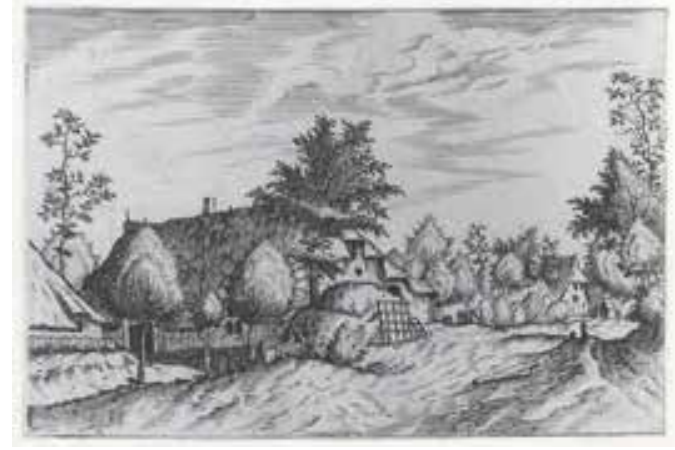

Fig. 2 Joannes and Lucas van Doetecum, after the Master of the Small Landscapes, Village Street, 1561, etching and engraving, $13.2 \times 19.5 \mathrm{~cm}$. Koninklijke Bibliotheek van België, Prentenkabinet, Brussels

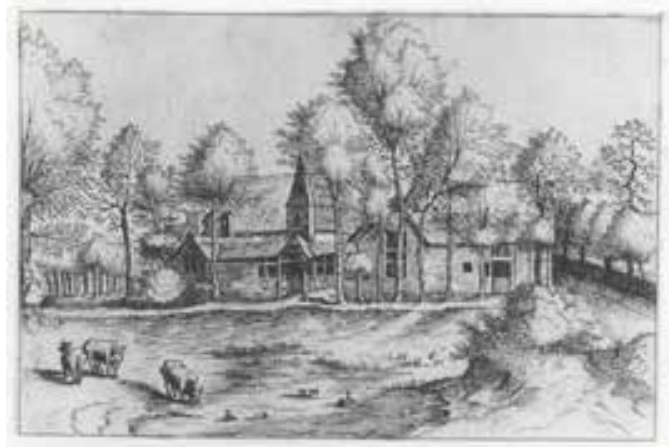

Fig. 4 Joannes and Lucas van Doetecum, after the Master of the Small Landscapes, Country Village with Church, 1561, etching and engraving, $13.2 \times 19.7 \mathrm{~cm}$. Koninklijke Bibliotheek van België, Prentenkabinet, Brussels

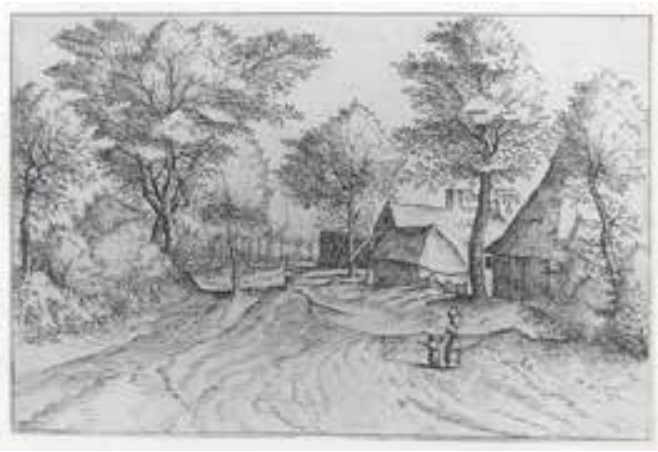

Fig. 3 Joannes and Lucas van Doetecum, after the Master of the Small Landscapes, Village Road, 1561, etching and engraving, 13.4 x $19.6 \mathrm{~cm}$., Koninklijke Bibliotheek van België, Prentenkabinet, Brussels

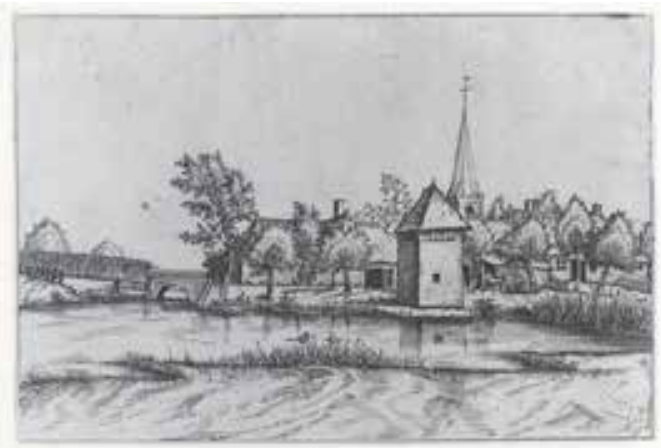

Fig. 5 Joannes and Lucas van Doetecum, after the Master of the Small Landscapes, Country Village with Church and Bridge, 1561, etching and engraving, $13.3 \times 19.4 \mathrm{~cm}$. Koninklijke Bibliotheek van België, Prentenkabinet, Brussels 


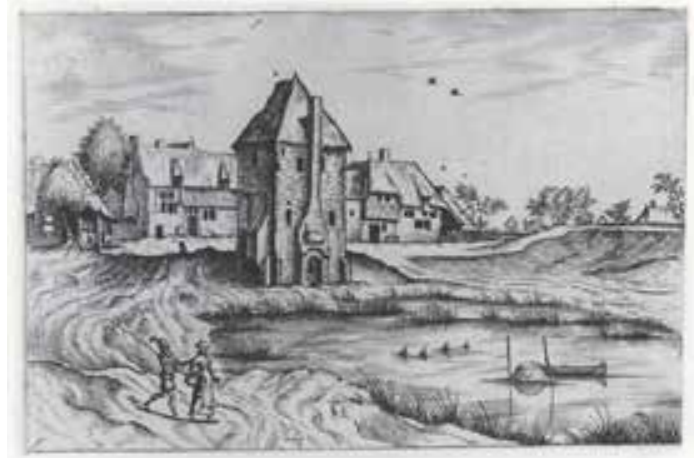

Fig. 6 Joannes and Lucas van Doetecum, after the Master of the Small Landscapes, Farms with Pond, 1561, etching and engraving, 13.3 x $19.8 \mathrm{~cm}$. Koninklijke Bibliotheek van België, Prentenkabinet, Brussels

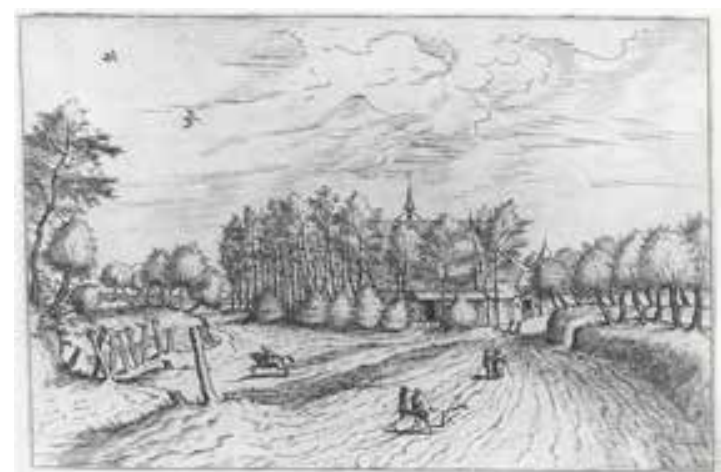

Fig. 7 Joannes and Lucas van Doetecum, after the Master of the Small Landscapes, Farm, 1561, etching and engraving, $13.2 \times 19.6$ $\mathrm{cm}$. Koninklijke Bibliotheek van België, Prentenkabinet, Brussels

According to many scholars, more than the particular content of the prints, it was the descriptive, almost documentary approach to rustic scenery in the Small Landscapes - that is, the formal example they set forth - that provided the artistic stimulus for Visscher's subsequent production of local Dutch views. ${ }^{5}$ As this model of landscape migrated from prints to paintings, it influenced the distinctive development of Dutch Golden Age landscape more broadly. Visscher's translations of the humble Brabantine views of the Small Landscapes, in other words, anticipated and indeed precipitated the new indigenous form of landscape art that emerged in the Northern Netherlands in the decades after their appearance.

Although Visscher's copies of the Small Landscapes are integral in charting his well-known trajectory toward the creation of innovative native Dutch landscapes, this article will suggest an alternative perspective on the way these prints may have operated in the north when they were published there in 1612. Rather than conceiving of his copied views as revolutionary or new, Visscher almost certainly understood them as retrospective rather than innovative, as embodying and re-presenting a venerable older Flemish tradition as much as anticipating a new pictorial model for Dutch landscapes. The question then arises: whywould Visscher have gone to such an effort to reproduce these old views and what resonances or associations might they have had for contemporary Dutch audiences? I believe there was good reason for Visscher, always the savvy businessman, to have been confident that old views of the Brabantine countryside would have found a receptive audience in Holland in 1612. Just three years into the Twelve Years' Truce (1609-21), these prints offered a nostalgic invocation of the region of the Southern Netherlands that had so recently been ceded to the Spanish in the brokering of a temporary peace. Thus, in addition to or apart from the role their formal power played in transforming the artistic idiom of landscape in Holland, the specific topographic content of Visscher's Small Landscapes recalled for Dutch audiences both an earlier era and a now-distant place.

To explore this hypothesis requires a careful examination of the prints themselves (figs. 8-15). Twenty-four of the etchings in Visscher's series are copied from Cock's original 1561 set. Along with a new title page, he also appended two additional prints at the end of the series. The last print, of a moated castle, has no precedent in Cock's work and seems to be related to some of Visscher's slightly later prints of nearby castles, while the penultimate print is a free copy loosely 
based on one of the views from Cock's 1559 set. $^{6}$ All the rest of Visscher's prints hue closely to Cock's original models, indicating that while Visscher augmented the series, he also sought to remain faithful in his reproductions to the original views.

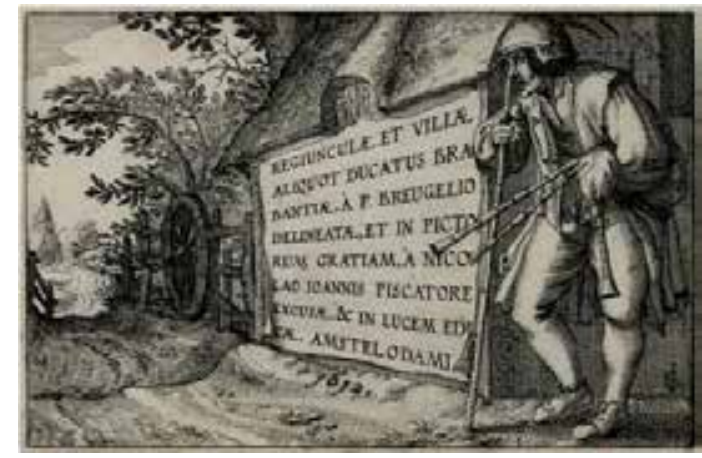

Fig. 8 Claes Jansz. Visscher, Title page, from the Regiunculae, et Villae Aliquot Ducatus Brabantiae ... series, 1612, etching, $10 \mathrm{x}$ $15.5 \mathrm{~cm}$. British Museum, London, 1936,1116.4 (artwork in the public domain)

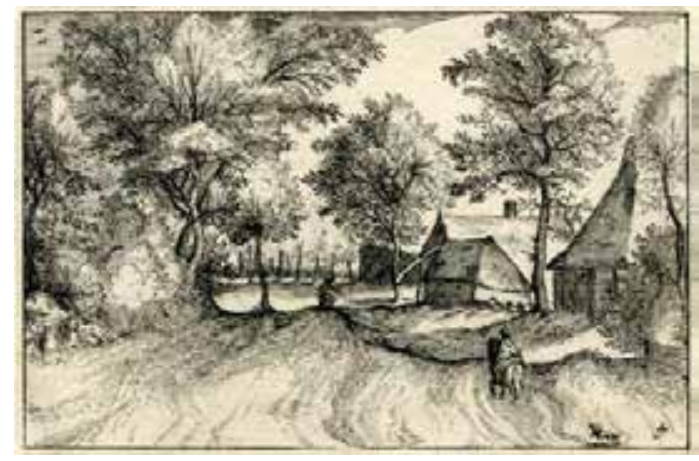

Fig. 10 Claes Jansz. Visscher, Village Road, no. 4 from the Regiunculae, et Villae Aliquot Ducatus Brabantiae ... series, 1612, etching, 10 x $15.5 \mathrm{~cm}$. British Museum, London, 1936,1116.6 (artwork in the public domain)

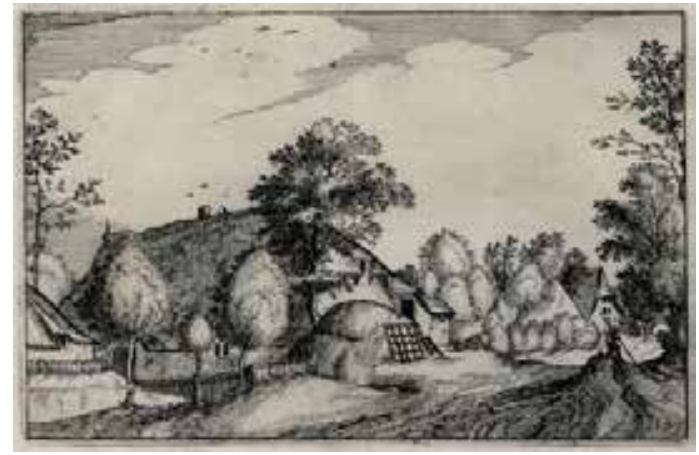

Fig. 9 Claes Jansz. Visscher, Village Street, no. 12 from the Regiunculae, et Villae Aliquot Ducatus Brabantiae ... series, 1612, etching, 10.1 x $15.6 \mathrm{~cm}$. British Museum, London, 1936,1116.14 (artwork in the public domain)

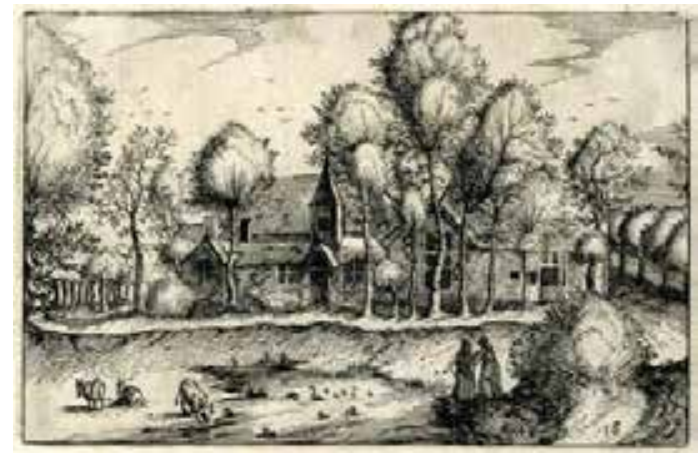

Fig. 11 Claes Jansz. Visscher, Country Village with Church, no. 18 from the Regiunculae, et Villae Aliquot Ducatus Brabantiae ... series, 1612, etching, $9.9 \times 15.4 \mathrm{~cm}$. British Museum, London, $1936,1116.20$ (artwork in the public domain)

6 It was a common practice among early seventeenth-century print publishers in both the Southern and Northern Netherlands to republish older plates. ${ }^{7}$ Visscher himself regularly bought up old plates and reissued them throughout the long duration of his career as a publisher. ${ }^{8}$ Nor were the Small Landscapes the only print series that he replicated when he could not attain original plates; he would later go on to produce copies of several other landscape print series, though this is, to my knowledge, the earliest instance of his doing so. ${ }^{9}$ Given how many secondhand plates were available in the north, including plates for Flemish landscapes, and his own skills as a landscape draftsman and etcher, it is perhaps all the more notable that Visscher went to the effort to produce new plates after these particular prints. He must have deemed them both significant enough to warrant being copied, with a broad enough appeal to garner a wide audience, and sufficiently difficult to obtain in Amsterdam to prove commercially viable - this despite the fact that the original prints had been reissued in Antwerp by Philips Galle in 1601 and his son Theodoor Galle some years thereafter. ${ }^{10}$ This suggests that the print markets in Antwerp and Amsterdam were isolated from one another, even after the Twelve Years' Truce, to a degree that made copying 
the plates a reasonable and attractive scheme. ${ }^{11}$

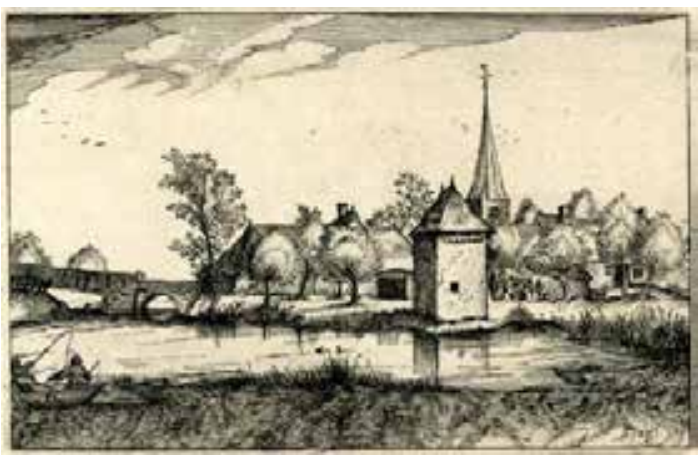

Fig. 12 Claes Jansz. Visscher, Country Village with Church and Bridge, no. 15 from the Regiunculae, et Villae Aliquot Ducatus Brabantiae ... series, 1612, etching, $9.9 \times 15.5 \mathrm{~cm}$. British Museum, London, 1936,1116.17

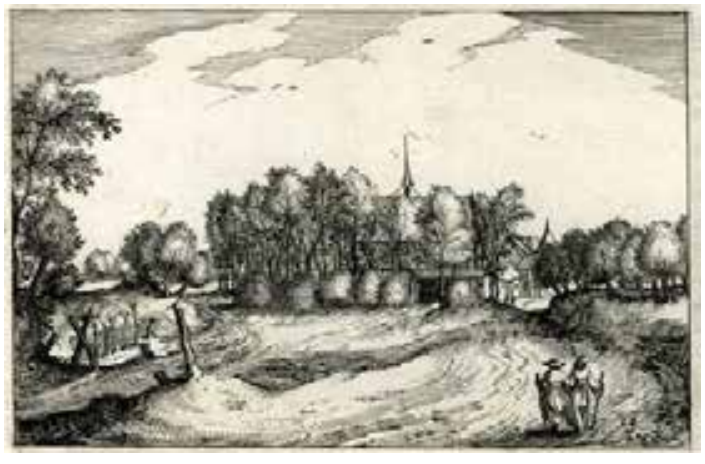

Fig. 14 Claes Jansz. Visscher, Farm, no. 13 from the Regiunculae, et Villae Aliquot Ducatus Brabantiae ... series, 1612, etching, $10 \mathrm{x}$ $15.7 \mathrm{~cm}$. British Museum, London, 1936,1116.15 (artwork in the public domain)

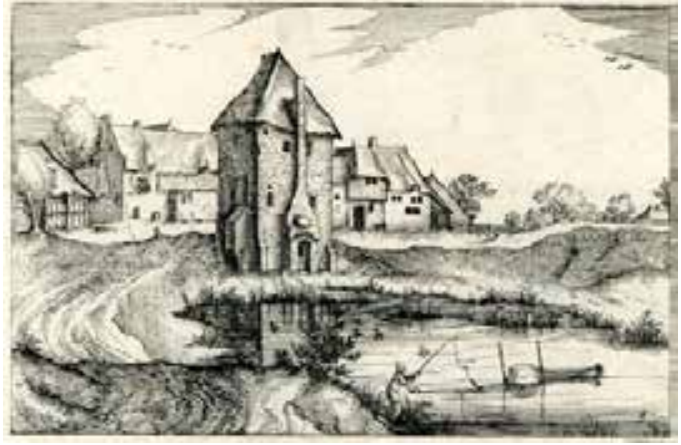

Fig. 13 Claes Jansz. Visscher, Farms with Pond, no. 9 from the Regiunculae, et Villae Aliquot Ducatus Brabantiae ... series, 1612, etching, 10.1 x $15.5 \mathrm{~cm}$. British Museum, London, 1936,1116.11

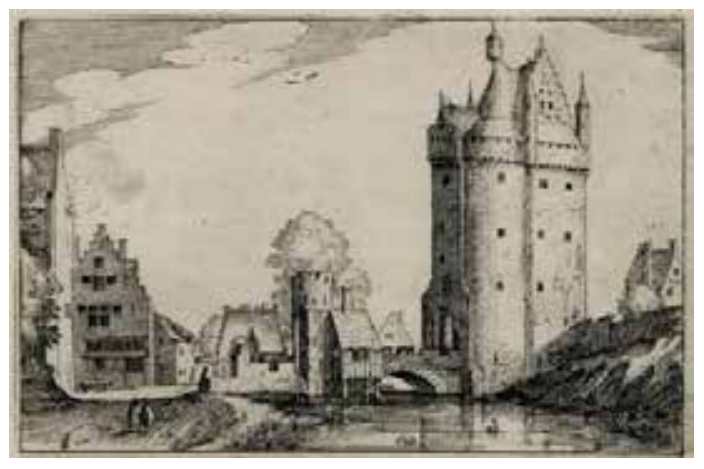

Fig. 15 Claes Jansz. Visscher, Roode Poort, no. 2 from the Regiunculae, et Villae Aliquot Ducatus Brabantiae ... series, 1612, etching, $9.9 \times 15.3 \mathrm{~cm}$. British Museum, London, 1936,1116.5 (artwork in the public domain)

Because he had to recreate the Small Landscapes rather than simply reprint existing plates, we can tell a great deal about what Visscher sought to maintain from the original prints and what aspects of the images he was willing to alter and adjust. Let us consider first the changes. ${ }^{12}$ Visscher numbered the prints in his series, thereby creating a clear sequence of views, while Cock's sets had been issued unnumbered. Visscher's versions are also smaller in scale than the original prints, measuring about $10 \times 16 \mathrm{~cm}$, compared to $13 \times 20 \mathrm{~cm}$. Although this slight reduction might have been a strategy to control costs (these smaller plates would require less copper), the reduced scale also makes the resulting views more compact and intimate. In addition to the overall reduction in size, Visscher also cropped most of the images at the edges, sometimes by tiny increments, sometimes to a more significant degree (compare figs. 2 and 9; 3 and 10; 4 and 11). These reductions tighten the centralized focus of the images by curtailing slightly their lateral expansiveness, bringing the views slightly closer to the viewer. Because of the reductions at the margins, the central views are now often more clearly framed by trees that rise along the edges, their foliage slightly fuller and softer, which suggests a record not just of a specific place but also a specific, fecund,season and atmosphere. These bushy trees create an enclosing boundary at the edges of the views, heightening the sense of quietude and intimacy they create for the viewer (compare 
figs.3 and 10; 4 and 11). The greater concentration of Visscher's scenes is also heightened by his treatment of the sky - his billowy clouds are more heavily defined compared to the stark blank skies or the horizontal hatching found in the original prints (compare figs. 3 and 10; 5 and 12). In most of Visscher's copies, hatching fills in the top corners of the prints, transforming their rectangular format by establishing an oval framing device at the top that encloses the landscape below (compare figs. 6 and 13; 7 and 14).

The overall tone of the prints - in part because of their compression but also because of Visscher's freer etching technique - is slightly darker or denser. While Cock's original prints, etched and engraved by the van Doetecum brothers, are stark in their clarity and precise in their contrasts, Visscher creates larger swathes of deep shadow, particularly in the immediate foreground of his views, which results in a more dramatic, unified atmosphere. The few figures included in the copies are set out in silhouette against patches of light in the middle ground (compare figs. 2 and 9; 3 and 10; 7 and 14). The darkened foreground and lighter middle ground also help to more forcefully pull the viewer's eye into the scene, an effect enhanced by the more strongly articulated lines in the curving sweep of the roads that frequently lead from the foreground into the middle distance.

9 In addition to these changes to the framing and atmosphere of the scenes, we see significant alterations to the staffage as well. Virtually all of Cock's original figures have been replaced or removed, their positions and activities changed, and new figures added. Some take up typical rural activities. Visscher added fishing scenes to two of the prints, possibly a punning reference to his own name (figs. 12, 13). ${ }^{13}$ However, most of Visscher's figures simply stroll or rest along a central road, with few references to any sort of work or toil. The figures in Cock's series often appear as awkward afterthoughts too small for their surroundings. By contrast, Visscher's occasional figures cohere seamlessly within their environment, their compositional integration and their easy repose heightening the sense of the pleasant peacefulness of these rural places (compare figs. 7 and 14).

10 For all these changes and adjustments, there is one important way in which Visscher was scrupulously faithful to his models. His copies are exacting in their accurate reproduction of the original architecture and arrangement of the views. Every building, indeed every window and wooden slat in every farmhouse, is assiduously recreated. Every fence, well, tree, and hedge appears again in precisely the same location, so as to maintain the organization and composition of each scene. Although Visscher's etched lines and forms are slightly more irregular than those of the van Doetecums, there is an obvious effort to render each detail of these structures and their setting with diligent accuracy. Thus, while Visscher treats the aspects of the prints that establish space, atmosphere, and human presence with much greater latitude and freedom, he is at great pains to carefully replicate the specific topographic details of each scene.

11 Visscher's desire to remain true to the topographic content of the Small Landscapes is indicated not only in the views themselves but in Visscher's title page (fig. 8). A large sheet tacked to the wall of a barn bears the title, which can be roughly translated as: "Some small residences and villas of the duchy of Brabant, delineated by P. Breugelio, and for the sake of painters engraved and published by Claes Jansz Visscher, Amsterdam." ${ }^{4}$ While he might as easily have proclaimed the series to be rustic country views of less specific provenance, Visscher clearly identifies the views as 
Brabantine. He then begins his series with one of the only views that depicts an easily identifiable monument, the Roode Poort of Antwerp, further tethering the rest of series to this particular geographical setting (fig. 15). ${ }^{15}$

12 There is another notable feature to Visscher's title page. He attributes the series to Pieter Bruegel, despite the fact that Hieronymus Cock did not identify the designer of the Small Landscapes at all, and Philips Galle had attributed them to Cornelis Cort in his 1601 edition. ${ }^{16}$ The large peasant holding a bagpipe and a walking stick placed next to the title sheet seems aimed at reinforcing this association with Bruegelian imagery. Visscher's attribution might be interpreted simply as a canny commercial ploy to boost sales, given the resurgence in Bruegel's posthumous reputation in the Netherlands at this time. ${ }^{17}$ But there was perhaps a further impetus. Just as the title page overtly states that these are views of Brabant, attaching Pieter Bruegel's name to the series further authenticates its Flemish origins. This also underscores the idea that Visscher was not marketing these views as contemporary or new images; rather, he deliberately stressed their venerable provenance. Visscher's title page thus functions both to locate and historicize his copies of the Small Landscapes by explicitly binding them to Brabant and to the past.

13 Visscher's investment in recreating the Small Landscapes suggests that he sensed a strong market for these retrospective Flemish images in the Dutch Republic. Indeed, he undertook a campaign to republish several other sixteenth-century Flemish landscapes around the same time. He likely purchased the plates for several series of landscapes, originally published in Antwerp by Hans van Luyck, from the estate sale of Cornelis Claes in 1610. ${ }^{18}$ These included the By Antwerpen series, twelve landscape views ostensibly representing the countryside around Antwerp, engraved by Adriaen Collaert after designs by Jacob Grimmer and first published by van Luyck around 1580. He also acquired the plates for a series of views of the environs of Brussels, engraved by Hans Collaert I and published by van Luyck around 1575-80. Visscher, following Cornelis Claes, attributed this series, perhaps opportunistically, to Hans Bol, another Flemish artist whose considerable posthumous reputation in the north would have added cachet to the series. ${ }^{19}$ Visscher's editions of these Flemish series include his name as publisher and are undated, but it is likely that he republished them within a few years of purchasing the plates, that is to say, exactly contemporaneous with his copies of the Small Landscapes. As a result of this campaign, Visscher was able to offer a substantial number of old Flemish landscapes for sale in his shop, all at about the same time. Although varied in compositional arrangement and the degree of specific detail, all of the series present, or purport to present, topographic views of the Brabantine countryside. The sheets of the Brussels series are even carefully labeled with the name of each location depicted. Visscher's Small Landscapes are therefore neither anomalous nor coincidental but must be viewed as part of his larger program to revive a particular type of sixteenth-century Flemish topographic landscape imagery. With the publication of these series, Visscher essentially cornered the market in early seventeenth-century Amsterdam for such Flemish views. ${ }^{20}$

14 Visscher would not have invested such effort and capital both in acquiring and copying plates for Flemish topographical landscapes without a firm conviction that these series would appeal to a wide audience and prove commercially profitable. One of Visscher's intended audiences for the Small Landscape copies, and likely his other Flemish series, was other artists. He specifically dedicated the Small Landscapes to other artists on his title page: "in pictorum gratiam." ${ }^{21}$ As exem- 
pla for artists, including painters, these prints disseminated a direct, documentary approach to depicting the landscape in a realistic, immediate way. In this way, the prints, not unlike sketches and drawings, served as tools, workshop models to be referred to in the course of composing other works. Visscher clearly foresaw the generative potential of the Small Landscapes; though there are no known Dutch prints or paintings that directly employ motifs or compositions from the Small Landscapes, there can be little doubt of their later artistic impact on Dutch landscape artists, beginning first and foremost with Visscher's own Dutch landscape prints, to be discussed in detail below. ${ }^{22}$

15 It is, however, extremely unlikely that Visscher's commercial goals for these series extended only to other artists. As Nadine Orenstein has cogently argued, Visscher's success in this field was due in large part to the fact that his landscapes could appeal to different segments of a wide art-purchasing market in a variety of ways. ${ }^{23}$ Scholars have long debated the appeal and significance of the newly naturalistic and topographic Dutch landscapes that appeared in the early decades of the seventeenth century in the wake of Visscher's enterprise. While some have read these landscapes in symbolic and religious terms, seeking to determine the scriptural significance of particular elements or structures within the landscapes, others have suggested a more holistic interpretation of the genre in a broadly Calvinist context as records and celebrations of God's natural creation. ${ }^{24}$ Others have pointed to the ways that these landscapes often called forth recent history and memory and helped to shape the contours of an emerging, specifically Dutch, geographical and cultural identity. ${ }^{25}$ Still others argue that Dutch landscapes must be understood within more specific urban contexts, in which both local pride and pleasure in rustic retreat shaped viewers' reactions to naturalistic views of their lived environment. ${ }^{26}$

16 Throughout these discussions, there has been little effort as yet to determine and elucidate the particular resonances of Visscher's Small Landscape copiesand his other reprinted Flemish landscapes, which were, after all, not views of local Dutch places. It is difficult now to reimagine how they were received in 1612 without the hindsight of their later artistic and formal influence, that is, without locating them in the formative first stages of an artistic trajectory that we know leads to the flourishing Golden Age of Dutch landscape. However, audiences in 1612 could not yet have foreseen this trajectory and therefore must have viewed the Small Landscapes in other terms. For them, the landscapes' resonances would not have been prospective or Dutch, but rather retrospective and Brabantine.

17 One especially receptive audience would have been homesick Southern Netherlanders who emigrated to the north in huge waves from the 1570 s on. ${ }^{27}$ Jan Briels has calculated that at least 46,000 people emigrated from Antwerp to the north between 1578 and 1589 alone, mostly settling in Amsterdam. In some northern towns and cities, southern émigrés as much as doubled the local population. These refugees brought with them a taste for art and luxury decorations, which as Eric Jan Sluijter has shown, proved an enormous spur for both the importation of paintings from Antwerp, as well as the indigenous production of paintings by émigré and northern artists alike. He stresses the nostalgic appeal of the Small Landscapes in particular for immigrants and has placed these images in the context of a wide array of textual sources pointing to a similar nostalgic impulse. ${ }^{28}$ There can be little doubt that Visscher, ever responsive to potential audiences for his prints, must have recognized the commercial possibilities in a vast, culturally sophisti- 
cated immigrant population that was both predisposed to patronize the arts and homesick for the south. ${ }^{29}$ For them, his Small Landscape copies would have directly and realistically recalled the rural regions of their abandoned homeland with a simplicity, candor, and apparent accuracy unmatched in any other prints then available. The invitation to walk into and through the villages and countryside of Brabant proffered by the prints made this distant region visually present and accessible. $^{30}$

18 However, the peaceful virtual tour constructed by the prints does not depict the Brabantine countryside as it existed in 1612. Devastated by the dislocations and depredations visited upon it during the preceding decades of war, Brabant's rural terrain had been transformed by the turn of the century into a wasteland that recovered only haltingly in the years of peace that the truce granted. ${ }^{31}$ Rather than documenting these true conditions, Visscher's copied series replaced the present reality with an ideal reconstruction of the region as it might have been known to immigrants in times past. This phenomenon is not unlike that noted by Anna Knaap in her discussion of views of rustic Dutch subjects and terrains from the early seventeenth century. With reference to Haarlem in particular, she notes that "during a period in which the Haarlem countryside underwent significant economic changes, artists rarely depicted any industrial innovations in their work. Eschewing the countryside's entrepreneurial aspects, they rendered it as a place of pleasure, stability, and communal harmony." Rather than documenting and embracing any precipitous and uncertain changes in the appearance, use and significance of the actual landscape, artistic renderings of the landscape might be characterized rather as essentially conservative and retrospective. ${ }^{32}$ Fueled by a powerful nostalgia for a lost place and a time gone by, Visscher's copies of the Small Landscapes promised audiences just such a retrospective journey, the opportunity to travel back in time as well as to traverse the widening distance between north and south.

19 This resonance would have been particularly poignant for immigrants in the north, who still held fast to the dream of a reunited Netherlands. Although without political representation in their adopted home in the north and therefore without an influential voice in political life at this time, Southern Netherlanders were among the strongest supporters of the continued war against Spain in the hopes that this would result in the restoration of the seventeen provinces into a single body politic. ${ }^{33}$ While the Twelve Years' Truce had finally brought a cessation to the hostilities between the Dutch and the Spanish and provided a de facto acknowledgment of the political legitimacy and independence of the new United Provinces, it also ratified the territorial loss of Brabant, Flanders, and the other southern provinces to Spain, a loss that had been a practical reality since the fall of Antwerp in 1585 but that was nonetheless still keenly felt in $1609 .{ }^{34}$ Southerners certainly had a great deal at stake in the debate on the future course of the war, hoping even after decades of assimilation into northern Dutch culture and society for the freedom to return to their native lands. This became increasingly urgent and fraught over time, since the Southern Netherlands and its inhabitants were, with the passing of time and the growing political, ideological, cultural, and religious differences between north and south, becoming increasingly foreign, or "hispanicized," according to Dutch popular opinion. ${ }^{35}$ The ambivalence and growing complexity of the immigrants' relationship to their own lost homeland were entirely elided in Visscher's copies of the Small Landscapes, which offered instead a reassuring and familiar memory that served simultaneously as a visual promise of peaceful restoration and of seamless reintegration. 
20 Pierre Nora's conception of lieux de memoire is particularly apt in this context. He theorizes that what he calls milieux de memoire, or active sites of cultural memory that are inhabited and experienced in the present, as in ritual, can be transformed into lieux de memoire, or fixed vestiges of a cultural past, when they are no longer actively experienced in the present. These lieux de memoire are essentially commemorative and nostalgic, creating a discontinuity between the present and the past. ${ }^{36}$ This is akin to the process of distancing that southern immigrants encountered in the early seventeenth century when faced with the breach between their current lived experience within the Dutch Republic and their nostalgia for their past homeland. The Small Landscape prints might well have served as a visual lieu de memoire, by which images of the Brabantine countryside became a locus for consolidating memories of a past now disconnected from a present, lived experience.

21 If displaced southerners were especially invested in the struggle for Netherlandish unity, the Twelve Years' Truce elicited a broader ideological interest in and debate about the fate of Brabant and the southern provinces. Although the main points of contention in the two years of negotiations that led up to the signing of the truce and in the resumption of war in 1621 focused primarily on economic and trade concerns rather than territorial ones, factions within the Republic nonetheless found it expedient to continue to promote the idea that the war was primarily driven by a desire to free their Southern Netherlandish brethren from the yoke of Spanish oppression. ${ }^{37}$ This position was also forcefully promulgated by the hard-line Protestants who sought to stem the perceived tide of Catholic dominion spreading across Europe, though this militant Protestant ideology was more concerned with confessional freedom than with territorial reconquest and political reunification. ${ }^{38}$ Even as the actual reunification of the Netherlands as a single nation became less and less likely from a pragmatic political perspective, the concept of natural Netherlandish unity sustained its ideological force. The early seventeenth century witnessed a surge in pamphlets, songs, popular plays, and prints promoting the idea of "Netherlandishness." ${ }^{39}$

22 Maps were one of the most powerful formats in which ideas of Netherlandish solidarity found visual form in the wake of the Twelve Years' Truce. In particular, Leo Belgicus maps, which had long represented the seventeen provinces bound together within the outline of a lion and which were published in large numbers in the United Provinces, represented the Netherlandish provinces as united rather than sundered. ${ }^{40}$ The Leo Belgicus map that Visscher himself published sometime between 1611 and 1621, titled "Novissima, et Acuratissima Leonis Belgici...," explicitly celebrates the peace and prosperity brought about by the truce (fig. 16). ${ }^{41}$ At the lower left, two female personifications of the Northern and Southern Netherlands, labeled " $t$ ' Vrye Neerlant (the Free Netherlands)" and " $t$ ' Neerlandt onder d'Aertshartogh Albertus (the Netherlands under Archduke Albert)," embrace one another and trample "d'Oude Twist (the Old Dispute)," beneath their feet. Around them, allegorical scenes extol the flourishing arts, trade, agriculture, and science and the thriving cities that resulted from the peace. The central lion drives the tip of a sword into the ground. From its hilt hang two medallions inscribed "for twelve years" in Latin and Dutch, referring to the years of peace guaranteed by the truce. To accentuate this point, at the bottom right corner slumps a figure in armor named "Sleeping War," the lion's sword thrust just behind him as though pinning him to the spot. The coats of arms of all seventeen provinces border the top of the map and twenty small views of both northern and southern cities decorate the two sides. Just as these framing devices suggest a unified territory, the map embodied within the contours 
of the lion joins the seventeen provinces together into a single, vital entity. This map bespeaks the optimism engendered by the cessation of hostilities and the prospect of peace, as well as the residual faith that the seventeen provinces of the Netherlands in some essential way were - and would continue to be - a united land, restored rather than divided by the truce. ${ }^{42}$

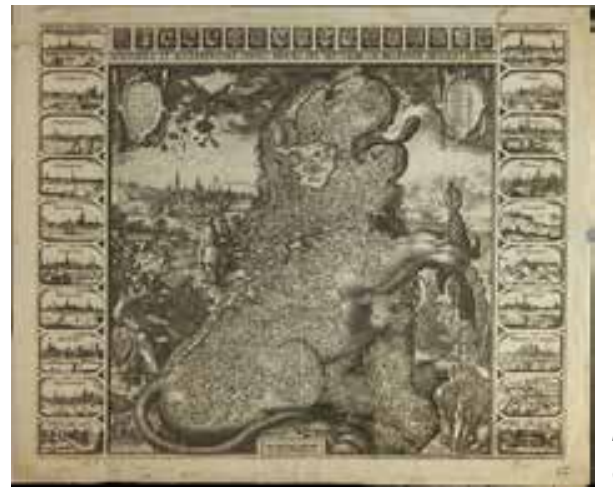

Fig. 16 Claes Jansz. Visscher, Novissima, et Acuratissima Leonis

Belgici ..., ca. $1610-20$, etching and engraving, $46.8 \times 56.9$

$\mathrm{cm}$. Koninklijke Bibliotheek van België, Brussels

23 Visscher's copied Small Landscapes perhaps reflect the same optimistic spirit. Although neither Visscher's title page nor the prints themselves contain overt or direct references to contemporary attitudes toward Netherlandish reunification, recent history and the debates surrounding Brabant and the Southern Netherlands could not but have informed the perceptions of contemporary viewers of the prints. By recreating views of an older Brabantine countryside, one not yet marred by the depredations of war, and circulating them at a moment when hopes were highest for a broad renewal of prosperity, Visscher offered Dutch audiences a vision of a past landscape of peace and tranquility that at long last, at least for a brief period, seemed once again within reach. Relinquished to the Spanish, Brabant was in a real sense quite removed from the United Provinces, but in their direct, unmediated format and composition, Visscher's Small Landscapes brought this southern province to the north with a visual immediacy that belied the political rift that separated the two. In the context of the nascent Dutch Republic, the prints might imaginatively restore and reanimate the lost unity of the Netherlands by offering viewers the opportunity to enter and traverse - visually, at least - this lost region to the south. By heightening the views' sense of intimate, placid harmony, while carefully replicating their topographic content, Visscher's series reconstructed an older, more peaceful Brabant that had existed prior to the long intervening years of war, eliding the very conflict that had disrupted and splintered the Netherlands from its previous unified state. At the same time, by making this Brabant appear decidedly present and proximate to contemporary Dutch audiences, the prints make a visual case for the natural and geographic connection conjoining the north and the south and thereby reinforce the justness of a fundamental national bond.

24 At precisely the same time that he issued his copies of the Small Landscapes, Visscher was also working on an analogous set of views of the rural surroundings of Haarlem, known as the Plaisante Plaetsen (figs. 17-20). This series of twelve etchings includes an elaborate title page and a table of contents identifying each of the scenes that follows. Although undated, the Plaisante Plaetsen have been convincingly dated between 1611, when Visscher began operations in the Kalverstraat, and $1613 .{ }^{43}$ In an important sense, Visscher's Plaisante Plaetsen are the perfect pendant to his version of the Small Landscapes. It is immediately evident why the two series are so 
often paired by art historians, since Visscher's Haarlem views are heavily indebted to the compositional logic and apparently unfiltered realism of the Small Landscapes. ${ }^{44}$ The two series share the same dimensions, suggesting that they could be easily collected together. As in the Small Landscapes, Visscher encourages the viewer of the Plaisante Plaetsen to explore the rural surroundings of Haarlem through a virtual tour of particular spots in the local countryside. His carefully orchestrated sequence of views is numbered and labeled in the table of contents, with a view of Zandtvoort at the beginning of this visual journey (fig. 17). The prints move in a wide arc from south to east to north around the outskirts of Haarlem, offering views of dunes, inns, woods, and bleaching fields along the way. Despite the resolute topographic specificity with which the prints distinguish the terrain of Holland from that of Brabant, the viewer is invited to enter the views of both series along similar roads leading out from the foreground (compare figs. 14 and 18). Resemblances in the rustic architecture and the mundane activities of the peasants and wayfarers encountered within the views suggest the comparable nature of rural life outside Antwerp and Haarlem (compare figs. 9 and 20; 10 and 19). The Plaisante Plaetsen share with the Small Landscapes their matter-of-fact presentation of mostly unremarkable rural structures in an immediate and naturalistic manner that engages the viewer directly. ${ }^{45}$ Taken together, as they must often have been, the Plaisante Plaetsen and the Small Landscapes suggest a visual parity and conformity between the two regions they record.

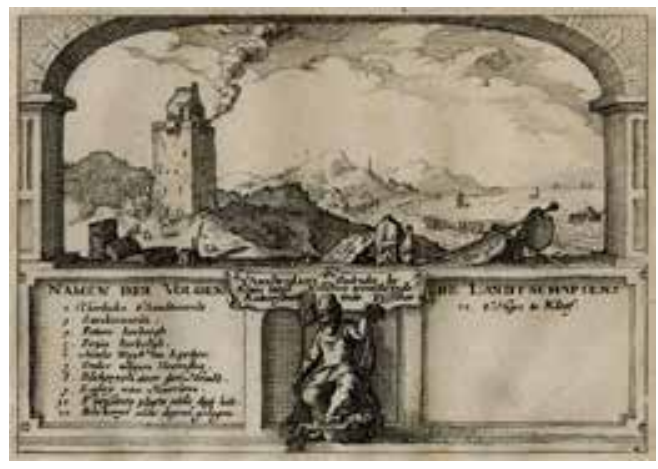

Fig. 17 Claes Jansz. Visscher, Beacon at Zandvoort, no. 2 from the Plaisante Plaetsen series, ca. 1611-12, etching, $10.3 \mathrm{x}$ $14.5 \mathrm{~cm}$. British Museum, London, 1987,1003.12

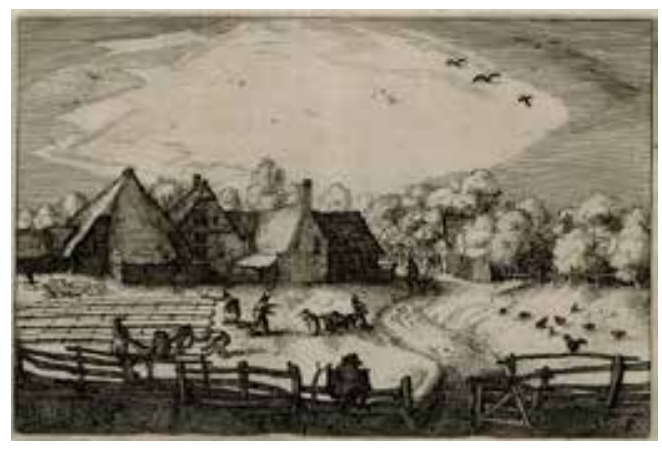

Fig. 19 Claes Jansz. Visscher, Bleaching Fields Near the Haarlemmer Hout, no.8 from the Plaisante Plaetsen series, ca. 1611-12, etching, $10.3 \times 15.6 \mathrm{~cm}$. British Museum, London, $1987,1003.18$

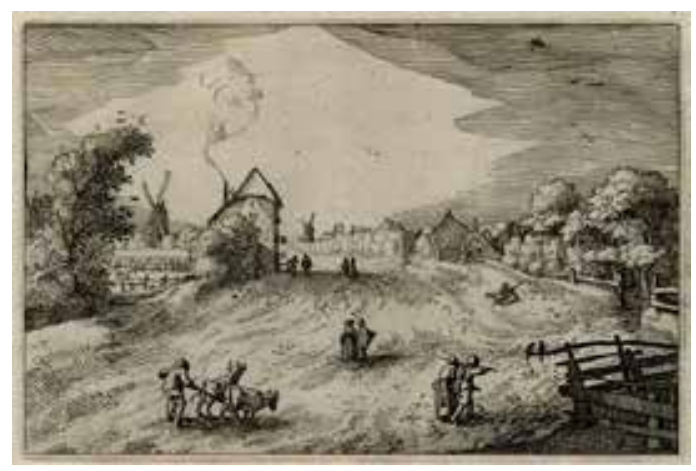

Fig. 18 Claes Jansz. Visscher, The Road Towards Leiden, no. 6 from the Plaisante Plaetsen series, ca. 1611-12, etching, $10.3 \times 15.9$ cm. British Museum, London, 1987,1003.16

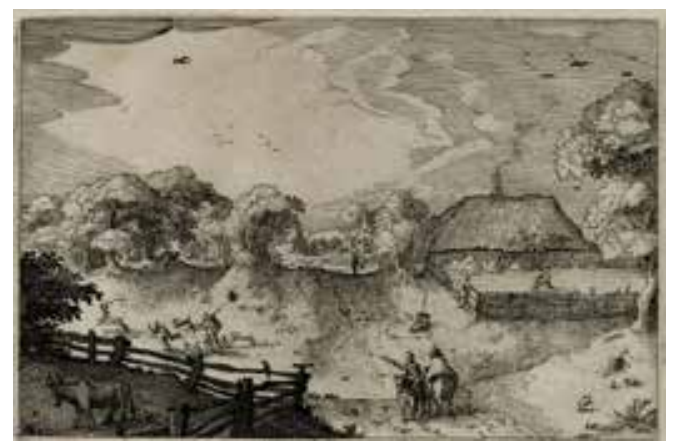

Fig. 20 Claes Jansz. Visscher, Road Near the Dunes, no. 10 from the Plaisante Plaetsen series, ca. 1611-12, etching, 10.3 x 15.7 cm. British Museum, London, 1987,1003.2 
25 Visscher's transposition of the pictorial model of the Brabantine landscapes to his local views of Haarlem points not only to the likeness between the two regions but also to a deeper thematic union. As with the views of towns and coats of arms, north and south, that frame his "Leonis Belgici" map, Visscher's Brabant and Haarlem series mirror one another and make a visual case for the natural and topographical correspondence that conjoined the two regions. In turn, this natural unity evokes a continuity of community that it was believed once bound the seventeen provinces together and that some hoped might yet be reestablished. The rural lands around Antwerp and Haarlem appear as two parts of the same natural territory and as complementary regions within a common national body. Because of the naturalism and seemingly unmediated directness of these rustic landscapes and the immediacy of the visual experience they engender, the two sets of prints together hold forth a promise of objective veracity that makes the claim for unity all the more visually and ideologically compelling.

This article has suggested the multivalence of Visscher's 1612 version of the Small Landscapes within the artistic, cultural, and political context around the time of the Twelve Years' Truce. On the one hand, the copied prints were deliberately retrospective, being recreations of older images attributed to the past great master Pieter Bruegel that were part of Visscher's broader program of Flemish landscape print republication; on the other, they provided the artistic impetus for Visscher and other artists in his wake to create very immediate views of their own local landscapes. The copied Small Landscapes might have evoked nostalgia for a lost home and past, particularly among the enormous population of southern immigrants and refugees who took up residence in the north. At the same time, the Brabantine views, by making this southern countryside palpably present, offered hope for a restoration - if only in print - of the inherent unity of the Netherlands, particularly when considered in tandem with Visscher's contemporaneous Plaisante Plaetsen prints. In these ways, Visscher's copies of the Small Landscapes were at once old and new, occupying a critical fulcrum between the Southern and Northern Netherlands, between artistic tradition and innovation, between aesthetic experience and ideological meaning, between a retrospective view of the past and hopes for the future. As such, they suggest the complexity of the migration that these Flemish topographic landscape prints underwent in their transference from Antwerp to Amsterdam in the early seventeenth century and the attendant revisioning of place, memory, and nation that they enabled for contemporary audiences.

\section{List of Illustrations}

Fig. 1 Title page, from "Multifariarum Casularum Ruriumq..., , the first set of the Small Landscapes, published by Hieronymus Cock (Antwerp, 1559) (artwork in the public domain)

Fig. 2 Joannes and Lucas van Doetecum, after the Master of the Small Landscapes, Village Street, 1561, etching and engraving, $13.2 \times 19.5 \mathrm{~cm}$. Koninklijke Bibliotheek van België, Prentenkabinet, Brussels (artwork in the public domain)

Fig. 3 Joannes and Lucas van Doetecum, after the Master of the Small Landscapes, Village Road, 1561, etching and engraving, 13.4 x $19.6 \mathrm{~cm}$., Koninklijke Bibliotheek van België, Prentenkabinet, Brussels (artwork in the public domain) 
Fig. 4 Joannes and Lucas van Doetecum, after the Master of the Small Landscapes, Country Village with Church, 1561, etching and engraving, 13.2 x19.7 cm. Koninklijke Bibliotheek van België, Prentenkabinet, Brussels (artwork in the public domain)

Fig. 5 Joannes and Lucas van Doetecum, after the Master of the Small Landscapes, Country Village with Church and Bridge, 1561, etching and engraving, $13.3 \times 19.4 \mathrm{~cm}$. Koninklijke Bibliotheek van België, Prentenkabinet, Brussels (artwork in the public domain)

Fig. 6 Joannes and Lucas van Doetecum, after the Master of the Small Landscapes, Farms with Pond, 1561, etching and engraving, 13.3 x $19.8 \mathrm{~cm}$. Koninklijke Bibliotheek van België, Prentenkabinet, Brussels (artwork in the public domain)

Fig. 7 Joannes and Lucas van Doetecum, after the Master of the Small Landscapes, Farm, 1561, etching and engraving, 13.2 x $19.6 \mathrm{~cm}$. Koninklijke Bibliotheek van België, Prentenkabinet, Brussels (artwork in the public domain)

Fig. 8 Claes Jansz. Visscher, Title page, from the Regiunculae, et Villae Aliquot Ducatus Brabantiae ... series, 1612, etching, 10 x $15.5 \mathrm{~cm}$. British Museum, London, 1936,1116.4 (artwork in the public domain)

Fig. 9 Claes Jansz. Visscher, Village Street, no. 12 from the Regiunculae, et Villae Aliquot Ducatus Brabantiae ... series, 1612, etching, 10.1 x $15.6 \mathrm{~cm}$. British Museum, London, 1936,1116.14 (artwork in the public domain)

Fig. 10 Claes Jansz. Visscher, Village Road, no. 4 from the Regiunculae, et Villae Aliquot Ducatus Brabantiae ... series, 1612, etching, 10 x $15.5 \mathrm{~cm}$. British Museum, London, 1936,1116.6 (artwork in the public domain)

Fig. 11 Claes Jansz. Visscher, Country Village with Church, no. 18 from the Regiunculae, et Villae Aliquot Ducatus Brabantiae... series, 1612, etching, 9.9 x $15.4 \mathrm{~cm}$. British Museum, London, $1936,1116.20$ (artwork in the public domain)

Fig. 12 Claes Jansz. Visscher, Country Village with Church and Bridge, no. 15 from the Regiunculae, et Villae Aliquot Ducatus Brabantiae .. . series, 1612, etching, 9.9 x $15.5 \mathrm{~cm}$. British Museum, London, 1936,1116.17 (artwork in the public domain)

Fig. 13 Claes Jansz. Visscher, Farms with Pond, no. 9 from the Regiunculae, et Villae Aliquot Ducatus Brabantiae... series, 1612, etching, 10.1 x $15.5 \mathrm{~cm}$. British Museum, London, 1936,1116.11 (artwork in the public domain)

Fig. 14 Claes Jansz. Visscher, Farm, no. 13 from the Regiunculae, et Villae Aliquot Ducatus Brabantiae . . series, 1612, etching, 10 x $15.7 \mathrm{~cm}$. British Museum, London, 1936,1116.15 (artwork in the public domain) 
Fig. 15 Claes Jansz. Visscher, Roode Poort, no. 2 from the Regiunculae, et Villae Aliquot Ducatus Brabantiae... series, 1612, etching, 9.9 x $15.3 \mathrm{~cm}$. British Museum, London, 1936,1116.5 (artwork in the public domain)

Fig. 16 Claes Jansz. Visscher, Novissima, et Acuratissima Leonis Belgici . ., ca. 1610-20, etching and engraving, 46.8 x $56.9 \mathrm{~cm}$. Koninklijke Bibliotheek van België, Brussels (artwork in the public domain)

Fig. 17 Claes Jansz. Visscher, Beacon at Zandvoort, no. 2 from the Plaisante Plaetsen series, ca. 1611-12, etching, $10.3 \times 14.5 \mathrm{~cm}$. British Museum, London, 1987,1003.12 (artwork in the public domain)

Fig. 18 Claes Jansz. Visscher, The Road Towards Leiden, no. 6 from the Plaisante Plaetsen series, ca. 1611-12, etching, 10.3 x $15.9 \mathrm{~cm}$. British Museum, London, 1987,1003.16 (artwork in the public domain)

Fig. 19 Claes Jansz. Visscher, Bleaching Fields Near the Haarlemmer Hout, no. 8 from the Plaisante Plaetsen series, ca. $1611-12$, etching, 10.3 x $15.6 \mathrm{~cm}$. British Museum, London, 1987,1003.18 (artwork in the public domain)

Fig. 20 Claes Jansz. Visscher, Road Near the Dunes, no. 10 from the Plaisante Plaetsen series, ca. 1611-12, etching, $10.3 \times 15.7 \mathrm{~cm}$. British Museum, London, 1987,1003.2 (artwork in the public domain)

* All translations by the author unless otherwise noted.

${ }^{1}$ On Visscher's biography and publishing practices, see M. Simon, "Claes Jansz. Visscher" (PhD diss., University of Fribourg, 1958); I. H. van Eeghen, "De familie van de plaatsnijder Claes Jansz Visscher," Amstelodamum77 (1990): 73-82; and Nadine Orenstein, Huigen Leeflang, Ger Luiten, and Christiaan Schuckman, "Print Publishers in the Netherlands, 1580-1620," in Ger Luijten et al., eds., Dawn of the Golden Age: Northern Netherlandish Art, 15801620(Amsterdam: Rijksmuseum, 1993); and Walter Gibson, Pleasant Places: The Rustic Landscape from Bruegel to Ruisdael(Berkeley: University of California Press, 2000), 45.

${ }^{2}$ For Cock's series, see F. W. H. Hollstein, The New Hollstein: Dutch and Flemish Etchings, Engravings, and Woodcuts, 1450-1700(Roosendaal, Netherlands, 1993-), vol. 5 (The van Doetecum Family), pt. 1, pp. 94-135, nos. 118-61 [hereafter abbreviated New Hollstein]. For recent scholarship on these series, with references to further literature, see Gibson, Pleasant Places, 1-26; and Alexandra Onuf, "Local Terrains: The Small Landscape Prints and the Depiction of the Countryside in Early Modern Antwerp" (PhD diss., Columbia University, 2006).

${ }^{3}$ Cock's 1559 title page reads: "Multifariarum casularum ruriumq. Lineamenta curiose ad vivum expressa. Vele ende seer fraeye ghe = leghentheden van diverssche Dorphuysinghen, Hoe-ven, Velden, Straten, ende dyer ghelijcken, met alderhande Beestkens verciert. Al te samen ghe-conterfeyt naer dleven, ende meest rontom Antwerpen gheleghen sijnde. Nu eerst nieuwe ghedruct 
ended wt laten gaen by Hieronymus Cock. 1559. Cum gratia \& privilegio Regis," the Latin portion of which translates as "Various cottages and places in the countryside. Carefully drawn in a lifelike manner." The Dutch inscriptions reads: "Many and very fine locations of various village houses, farms, fields, roads and the like, ornamented with all sorts of animals. Altogether drawn in a lifelike manner, and mostly located around Antwerp. Now first printed and published by Hieronymus Cock. 1559. With grace and privilege of the King." Cock's 1561 title page reads: "Praediorum villarum et rusticarum casularum icones elenoantissi-mae ad vivum in apre deformatae. Libro Secundo 1561. Hieronymus Cock excudebat cum gratia et privilegio," which translates as: "Pictures of farms, country houses, and rustic villages elegantly engraved in a lifelike manner. Second Book 1561. Hieronymus Cock published [them] with grace and privilege." See New Hollstein, 94, 110-11, figs. a and b. For discussion of the contemporary meaning and use of the term naer het leven, see David Freedberg, Dutch Landscape Prints of the Seventeenth Century(London: British Museum Publications, 1980), 10-11; and Walter Melion, Shaping the Netherlandish Canon: Karel van Mander's Schilderboek(Chicago: University of Chicago Press, 1991), 63. See also Peter Parshall, "Imago Contrafacto: Images and Facts in the Northern Renaissance", Art History16, no. 4 (1993): 554-79; and Claudia Swan, "Ad vivum, naer het leven, from the life: Defining a Mode of Representation," Word and Image 11 (1995): 353-72.

${ }^{4}$ The first evidence of Visscher's interest in topographic imagery can be found in his drawings of sites around Amsterdam and Haarlem, which he produced en plein airas early as 1607. Some of these drawings later served as designs for his Plaisante Plaetsenseries, published around 1611-13, which are discussed in detail below. Even earlier, Hendrick Goltzius made three drawings of landscapes near Haarlem, dated 1603, that are likely the earliest examples of the tendency to sketch from life among Dutch artists. Golztius's and Visscher's propensity for drawing topographic sketches directly from life has been attributed to the influence of the Small Landscapes, with which this essay will be primarily concerned, and indicate that Visscher may have first encountered Cock's Small Landscapesseveral years before he issued his copies and his own landscape print series. For these early drawings, see Luijten et al., Dawn of the Golden Age, 642, 650-55. ${ }^{5}$ For instance, see Freedberg, Dutch Landscape Prints, 21-22, 28; Christopher Brown, Dutch Landscape: The Early Years, Haarlem and Amsterdam 1590-1650.(London: National Gallery, 1986), 18-19, 110-11; and Gibson, Pleasant Places, 1-26, 39-42.

${ }^{6}$ On the organization of Cock's original two series and the evidence that Visscher relied on the 1561 series rather than Philips Galle's more recent 1601 edition published in Antwerp, see Onuf, "Local Terrains," 252 and Appendix I. The final print in Visscher's series may represent a castle in Warmond, near Leiden. Visscher's interest in documenting local castles can be seen in his slightly later series of 1617 Four Castles in Holland and Utrecht. See F. W. H. Hollstein, Dutch and Flemish Etchings, Engravings, and Woodcuts, Ca. 1450-1700(Amsterdam: M. Hertzberger, 1949-), 38:87-88, nos. 165-68 [hereafter abbreviated Hollstein]. The one print that Visscher based on a print from Cock's 1559 series is also, notably, the one that differs most starkly from the original, with much more lush foliage, slightly different contours in the road, and a completely different arrangement of staffage. It is possible that Visscher was working from an intermediate source for this composition, such as an etched or drawn copy of the original print, and thus felt free to take greater liberties with its composition and form.

${ }^{7}$ The widespread republication of sixteenth-century prints in the seventeenth century resulted in the continuing dissemination and availability of older prints on the art market. See Manfred Sellink, "De Markt voor Grafiek in Antwerpen: De Zestiende en Zeventiende Eeuw," in Copy- 
right Rubens: Rubens en de Grafiek, ed. Nico Van Hout (Ghent: Ludion, 2004), 150-55; and Ann Diels, The Shadow of Rubens: Print Publishing in 17th-Century Antwerp: Prints by the History Painters Abraham Van Diepenbeeck, Cornelis Schut and Erasmus Quellinus II(Turnhout, Belgium: Harvey Miller Publishers, 2009).

${ }^{8}$ The number of prints Visscher published from secondhand plates equaled the number of prints he published from original plates created in his shop. See Orenstein et al., "Print Publishers," in Luijten et al., Dawn of the Golden Age, 189.

${ }^{9}$ Later instances of Visscher's copied series include landscapes after Esaias van de Velde first published by Beerendrecht, dated 1614 (Hollstein, 38:148, nos. 319-24), and Boetius à Bolswert's series of landscapes after Abraham Bloemaert, dated 1620 (Hollstein, 38:141-44, nos. 266-91). ${ }^{10}$ The title page for Theodoor Galle's edition of the Small Landscapesis undated, though Eric Jan Sluijter has proposed that it appeared in 1610. See Eric Jan Sluijter, "On Brabant Rubbish, Economic Competition, Artistic Rivalry, and the Growth of the Market for Paintings in the First Decades of the Seventeenth Century," Journal of Historians of Netherlandish Art1, no. 2 (2009): www.jhna.org.

${ }^{11}$ This particular case appears to be at variance with broader indications that the import and trade in Flemish art in the Northern Netherlands, as well as the emigration of Flemish artists, was widespread and largely unhindered despite the military and political hostilities between the two regions. See Sluijter, "On Brabant Rubbish," part III; and Diels, The Shadow of Rubens.

${ }^{12}$ Walter Gibson and Tanja Michalsky have also assessed the alterations that Visscher made in his copies of the Small Landscapes. Michalsky concludes that these changes enhance the viewer's involvement in the scenes, thus establishing a visual idiom that Visscher likewise exploited in his Plaisante Plaetsenseries and other local landscapes to figure the especially close relationship between the Dutch and their land. See Gibson, Pleasant Places, 39-42; and Tanja Michalsky, "Die Natur der Nation: Überlegungen zur 'Landschaft' als Ausdruck nationaler Identität," in Europa im 17. Jahrhundert: Ein Politischer Mythos und seine Bilder, ed. Klaus Bussmann and Elke Anna Werner (Stuttgart: Franz Steiner Verlag, 2004), 345-46.

${ }^{13}$ In a more obvious reference to himself, Visscher prominently includes a fisherman with his nets in the center of the table of contents in front of his address in his Plaisante Plaetsenseries, about which more will be said below. See Hollstein, 38: 85, no. 150.

${ }^{14}$ The title page is in Latin: "Regiunculae, et villae aliquot ducatus Brabantiae, à P. Breugelio delineatae, et in pictorum gratiam, à Nicolao Ioannis Piscatore excusae, \& in lucem editae. Amstelodami. 1612." See Hollstein, 38:144, no. 292. For commentary, see Gibson, Pleasant Places, 41-42; and Michalsky, "Natur der Nation," 344.

15 The print of the Roode Port of Antwerp has been identified based on, among other sources, a drawing in the Antwerp Sketchbook in the Berlin Kupferstichkabinett (inv. no. 79 C 2, fol. 46 verso), which shows this gate with the city of Antwerp behind it. In personal communication, Dries Lyna has noted that this was the gate that led north out of the city of Antwerp toward the northern provinces and might thus have been especially resonant for Antwerpers living in the United Provinces.

${ }^{16}$ For a summary of the many proposals regarding the designer's identity, see Nadine Orenstein, ed., Pieter Bruegel the Elder: Drawings and Prints(New Haven, Conn.: Yale University Press, 2001); and Onuf, "Local Terrains," 23-25, both with further references.

${ }^{17}$ Larry Silver, "The Importance of Being Bruegel: The Posthumous Survival of the Art of Pieter Bruegel the Elder," in Pieter Bruegel the Elder: Drawings and Prints, 67-84. 
${ }^{18}$ The stock list from the Claes auction survives in Wolfenthal. For a discussion of Claes as a print dealer and an identification of many of the prints described in the catalogue he published in 1609, entitled the "Const ende Caert-Register," see H. W. de Kooker and B. van Selm, Boekcultuur in de Lage Landen, 1500-1800: Bibliografie van publicaties over particulier boekenbezit in Noord-en Zuid-Nederland, verschenen voor 1991(Utrecht, 1993), 217-25, especially note 199. For further assessment of these series and their significance in Visscher's early publishing career, see Gibson, Pleasant Places, 38.

${ }^{19}$ For the two series, see New Hollstein, vol. 13 (The Collaert Dynasty), pt. 5, pp. 216-32, nos. 1229-52 (Brussels series) and pp. 233-40, nos. 1253-64 (Antwerp series). Ann Diels has written the most comprehensive analysis of these series. See Ann Diels, "Hans Collaert I," in Met passer en penseel: Brussel en het oude hertogdom Brabant in beeld(Brussels: Dexia, 2000), 206-10; and Diels, "Introduction," New Hollstein, vol. 13 (The Collaert Dynasty) (2005), part I, p. li, note 110. See also Stefaan Hautekeete, "Van stad en land: Het beeld van Brabant in de vroege topografische tekenkunst," in Met passer en penseel: Brussel en het oude hertogdom Brabant in beeld(Brussels: Dexia, 2000), 46-57, especially 52-53. Hans Bol had emigrated to Amsterdam in 1591, where he lived and worked until his death in 1593. Jacob Savery and Frans Boels trained in his workshop during their time in the city. As a result, his work and reputation were widely appreciated in the Northern Netherlands. See A. A. van Suchtelen, "Bol, Hans," in Allgemeines Künster-Lexicon: Die Bildenden Künstler aller Zeiten und Völker, ed. K. G. Saur, (Munich: Saur, 1996), 12:359-60. Although Cornelis Claesz.' stocklist also describes the series as by Bol, Visscher's attribution has been disputed by scholars, who believe that the drawings related to this series are inconsistent with Bol's style. See An Zwollo, "Hans Bol, Pieter Stevens en Jacob Savery, enige kanttekeningen," Oud Holland84, no. 4 (1969): 298-302; and Dutch, Flemish and German Drawings, auction catalogue, Christie's Amsterdam, November 30, 1987, cat. nos. 6, 12-18.

${ }^{20}$ Visscher's copies of the Small Landscapeswent on to be published at least two more times in the later seventeenth century, by Pieter de Reyger and Joachim Bormeester in Amsterdam, indicating the longevity of their popularity as well as the diffusion of Visscher's stock.

${ }^{21}$ The phrase translates as "for the sake of painters." In a recent article, Boudewijn Bakker makes the case that Hieronymus Cock intended many of his print series for other artists, particularly painters. Several of his title pages, like Visscher's, specifically dedicated his prints to artists, and Bakker convincingly shows that even those series without such explicit dedications, including several landscape series, were marketed to this receptive audience. Given the long history of recommending print series of all sorts, including landscapes, to artists, and Visscher's own common use of this formula on several of his title pages, we might view Visscher's dedication of the Small Landscapecopies to the use of artists as a commonplace as much as a targeted, specific recommendation. See Boudewijn Bakker, “Pictores adeste!' Hieronymus Cock Recommending His Print Series," Simiolus: Netherlands Quarterly for the History of Art33 (2007): 62-63.

${ }^{22}$ There are examples of the Small Landscapes being used as models in some of the large painting workshops in Antwerp in the late sixteenth and early seventeenth centuries. See Alexandra Onuf, "Small Landscapes in Seventeenth-Century Antwerp," Burlington Magazine150, no. 1260 (2008): 190-93.

${ }^{23}$ Nadine Orenstein, "Marketing Prints to the Dutch Republic: Novelty and the Print Publisher," Journal of Medieval and Early Modern Studies28, no. 1 (1998): 156.

${ }^{24}$ H. J. Raupp, "Zur Bedeutung und Symbol für die holländische Landschaftsmalerei des 17. Jahrhunderts," Jahrbuch der Staatlichen Kunstsammlungen in Baden-Württenberg17 (1980): 
85-110; Josua Bruyn, “Toward a Scriptural Reading of Seventeenth-Century Dutch Landscape Painting," in Masters of Seventeenth-Century Landscape Painting, ed. P. C. Hutton (Boston: Museum of Fine Arts, 1987), 84-103; Reindert Falkenburg, "De betekenis van het geschilderde Hollandse landschap van de zeventiende eeuw: Een beschouwing naar aanleiding van enkele recente interpretaties," Theoretische Geschiedenis16 (1989): 131-53; and Boudewijn Bakker, "Levenspelgrimage of vrome wandeling? Claes Visscher en zijn serie Plaisante Plaetsen," Oud Holland107, no. 1 (1993): 97-115. See also Reindert Falkenburg, "Calvinism and the Emergence of Dutch Seventeenth-Century Landscape Art: A Critical Evaluation," in Seeing Beyond the Word: Visual Arts and the Calvinist Tradition, ed. Paul Corby Finney (Cambridge: Eerdmans, 1999), 343-68. ${ }^{25}$ Egbert Haverkamp Begemann and Alan Chong, "Dutch Landscape Painting and Its Associations," in The Royal Picture Gallery, Mauritshuis, ed. H. R. Hoetink (Amsterdam: Meulenhoff/ Landshoff, 1985), 56-67; Brown, Dutch Landscape: The Early years, 11-34, especially 26-30; Simon Schama, "Culture as Foreground," in Masters of Seventeenth-Century Dutch Landscape Painting, ed. Peter C. Sutton (Boston: Museum of Fine Arts, 1987), 64-83; Catherine Levesque, Journey through Landscape in Seventeenth-Century Holland: The Haarlem Print Series and Dutch Identity(University Park, Pa.: Pennsylvania State University Press, 1994); Ann Jensen Adams, "Competing Communities in the 'Great Bog of Europe': Identity and 17th-Century Dutch Landscape," in Landscape and Power, ed. W. J. T. Mitchell (Chicago: University of Chicago Press, 1994), 35-76; and Michalsky, "Natur der Nation," 333-54.

${ }^{26}$ Huigen Leeflang focuses on the significance of Visscher's Plaisante Plaetsenseries with reference to Haarlem's particular history and the city's representation in literary works, as well as the artistic milieu established there in the early seventeenth century. See Huigen Leeflang, "Dutch Landscape: The Urban View: Haarlem and Its Environs in Literature and Art, 15th-17th Century," Nederlands Kunsthistorisch Jaarboek48 (1997): 53-115. Elsewhere, he makes a closer study of the connection between the Haarlem landscapes and laudatory literary descriptions of the city. See Huigen Leeflang, "Het landschap in boek en prent: Perceptie en interpretatie van vroeg zeventiende-eeuwse Nederlandse lanschapsprenten," in Nederland naar't leven: Landschapsprenten uit de Gouden Eeuw, ed. Boudewijn Bakker and Huigen Leeflang (Zwolle: Waanders, 1993), 18-32, which also provides an overview of the multiplicity of approaches to interpreting Dutch landscape prints. Most recently, Walter Gibson has overtly rejected the scriptural interpretation of early Dutch landscapes, arguing instead that rustic landscapes offered a locus amoenusfor urbanites in need of relaxation and rejuvenation, a "playground" for armchair recreation. Gibson, Pleasant Places, especially chapters $3-5$.

${ }^{27}$ J. G. C. A Briels, Zuid-Nederlandse Immigratie 1572-1630(Haarlem: Fibula-Van Dishoeck, 1978).

${ }^{28}$ Ann Jensen Adams has also touched upon the idea that Dutch landscapes had a particular appeal to immigrants from the south, and that they engendered nostalgia in contemporary Dutch viewers, though she does not conjoin these two observations. Sluijter demonstrates that cheap paintings from Antwerp flooded the northern market after the signing of the truce. These imports, intended to meet the demand of an immigrant clientele, were responsible for changing the patterns of both production and reception of art in the north. This evidence of the wide availability of southern paintings in the north runs counter to my hypothesis that the market for prints might have been less open, thus inspiring Visscher to copy the Small Landscapesin Amsterdam despite their availability in Antwerp. See Sluijter, "On Brabant Rubbish," part III, especially notes 68 and 70 for the nostalgic invocation of the south; and Adams, "Competing Communities," 
$35-76$.

${ }^{29}$ Visscher himself was a native of Amsterdam, and archival evidence suggests that the Visschers can be documented there since at least 1529. See I. H. van Eeghen, "De familie," 73.

${ }^{30}$ David Freedberg has convincingly established that landscape prints offered seventeenth-century audiences the possibility of armchair travel; from the safety and comfort of home, the viewer could be transported to places far and near. In the argument that follows, I suggest that in addition to traversing distances virtually, Visscher's Small Landscapecopies provided an opportunity for virtual time travel as well by presenting a distant place as it existed in times past. See Freedberg, Dutch Landscape Prints, especially 9-20.

${ }^{31}$ The state of the Brabantine countryside after years of serving at the front line during the war is amply illustrated in contemporary texts, songs, and images. Songs from the turn of the century present Brabant and Flanders as "spoiled, destroyed, disgraced," often as a consequence of the merciless behavior of soldiers. See "Brabant en Vlaanderen in nood" and "Boeren-Litany," in Johannes van Vloten, Nederlandsche geschiedzangen naar tijdsorde gerangschikt en toegelicht(Amsterdam: K.H. Schadd, 1864), 370-73, 395-97. Frans Hogenberg's print series documenting the war, Scenes of the Religious and Civil Wars from the History of the Netherlands, France and England from 1559, published continuously over a number of years as the events of the war unfolded, highlight the adverse effects of particular battles on the countryside and its inhabitants, as for instance in his prints of the sieges of Dalen and Oosterweel, among many others. See Karel Kinds, Kroniek van de opstand in de Lage Landen, 1555-1609 ([Netherlands]: ALNU, 1999). The devastation of the countryside became a regular iconographic feature of both prints and paintings produced in Antwerp through the latter decades of the sixteenth and early decades of the seventeenth century. Notably, in the final edition of the Small Landscapes themselves, published by Johannes Galle in the 1630s or 1640s, the original plates were reworked to include marauding soldiers and battles taking place in the foreground and middle ground of these formerly peaceful and idyllic countryside views. For a full account of the circumstances in rural Brabant and the literary and artistic response to these circumstances, see Onuf, "Local Terrains," 180-205.

${ }^{32}$ See Anna Knaap, "From Low-Life to Rustic Idyll: The Peasant Genre in 17th-Century Dutch Drawings and Prints," Harvard University Art Museum Bulletin4 (1996): 30-59.

${ }^{33}$ The restoration of a united Netherlands promoted in the early seventeenth century relied on a conception of the Netherlands as a single entity that was of very recent and fragile origins. The local and provincial privileges of each region had for centuries trumped any effort to bind the Netherlands together into a unified political entity, as Charles V and Philip II recognized. Likewise, the diversity of confessional faiths and linguistic groups in the Netherlands made efforts to appeal to religious or cultural singularity impracticable. The idea of a patria,or nation of the Netherlands, only began to take shape in the mid-sixteenth century and was largely forged through collective anti-Spanish sentiment and rhetoric. On the development and limits of notions of Netherlandish nationhood, see Alastair Duke, "The Elusive Netherlands: The Question of National Identity in the Early Modern Low Countries on the Eve of the Revolt," in Dissident Identities in the Early Modern Low Countries(Farmham, England, and Burlington, Vt.: Ashgate, 2009), 9-51; and Alastair Duke, "In Defence of the Common Fatherland: Patriotism and Liberty in the Low Countries, 1555-1576," in Networks, Regions and Nations: Shaping Identities in the Low Countries, 1300-1650, ed. Robert Stein and Judith Pollmann (Leiden: Brill, 2010), 217-39, with further literature.

${ }^{34}$ Jonathan Israel, The Dutch Republic: Its Rise, Greatness, and Fall, 1477-1806, Oxford History of 
Early Modern Europe (Oxford and New York: Oxford University Press, 1995).

${ }^{35}$ Judith Pollmann, “Brabanters do fairly resemble Spaniards after all': Memory, Propaganda and Identity in the Twelve Years' Truce," in Public Opinion and Changing Identities in the Early Modern Netherlands: Essays in Honour of Alastair Duke, ed. Judith Pollmann and Andrew Spicer, Studies in Medieval and Reformation Traditions 121 (Leiden: Brill, 2007), 211-27; and Judith Pollmann, "No Man's Land: Reinventing Netherlandish Identities, 1585-1621," in Networks, Regions and Nations: Shaping Identities in the Low Countries, 1300-1650, ed. Robert Stein and Judith Pollmann (Leiden: Brill, 2010), 246-47.

${ }^{36}$ See Pierre Nora, Realms of Memory: The Construction of the French Past, ed. Lawrence D Kritzman, trans. Arthur Goldhammer, 3 vols., European Perspectives (New York: Columbia University Press, 1996), 1-20. My sincere thanks to Irene Schaudies for pointing me toward this reference. ${ }^{37}$ This position became more and more difficult to maintain, politically as well as rhetorically, in the face of the growing evidence that their countrymen to the south did not in fact wish to be freed from Spain but had become staunch loyalists. This was made most strikingly clear in the aftermath of Prince Maurits's Flemish campaign in 1600, which was expected to illicit the spontaneous revolt of the southerners against the Spanish. Not only did this revolt fail to materialize, but Maurits was shocked to discover that soldiers of the Republic's army suffered attacks from the local population. Pollmann, "No Man's Land," 248-49.

${ }^{38}$ On the other side of the debate, Johan van Oldenbarnevelt sought a permanent peace and the recognition of the independence of the United Provinces, even at the expense of the permanent loss of Brabant and Flanders, and "did not regard the conquest of Brabant and Flanders as an integral and natural part of their war aims." See A. T. van Deursen, "The Dutch Republic, 1588-1780," in History of the Low Countries, ed. J. C. H. Blom and E. Lamberts, trans. James C. Kennedy, new ed. (New York and Oxford: Berghahn Books, 2006), 155. Jonathan Israel suggests that the militant Protestants were likewise not focused on territorial reconquest. See Israel, The Dutch Republic, 419-20. The political debate about the war became complicated by the religious controversy that arose between the Remonstrants and the Counter-Remonstrants. The doctrinal struggles between these two camps became so heated that the nascent United Provinces teetered on the brink of civil war by the time of the publication of the Remonstrance in 1610. Issues of doctrinal policy became so politically charged as to have a significant impact on the course of military and diplomatic decisions, particularly in regards to the course of the war against Spain. See William van Doodewaard, "Remonstrants, Contra-Remonstrants and the Synod of Dort (1618-1619): The Religious History of the Early Dutch Republic," Canadian Journal of Netherlandic Studies28 (2007): 140-65. ${ }^{39}$ Pollmann, "No Man's Land," 251-57.

${ }^{40}$ The Leo Belgicusdesign was first employed by Austrian cartographer Michael Aitzinger in 1583. It is worth noting that this same format was later used for maps of the province of Holland, including by Visscher himself in 1633 (Hollstein, 38:111, no. 221). By then, the Leo Belgicusform had effectively shifted from symbolizing Netherlandish unity to Holland's supremacy; however, this development did not take place until long after the end of the truce and the optimism that it engendered. For a summary of Leo Belgicusiconography, see Jan Roegiers and Bart van der Herten, eds., Eenheid op Papier: De Nederlanden in Kaart van Keizer Karel tot Willem I(Leuven: Davidsfonds, 1994). For an analysis of the history of cartographic representations of the seventeen provinces united and their role in the formation of Netherlandish identity, including the Leo Belgicus, see Paul Regan, "Cartography, Chorography and Patriotic Sentiment in the Sixteenth-Century Low Countries," in Public Opinion and Changing Identities in the Early Modern Netherlands: 
Essays in Honour of Alastair Duke, ed. Judith Pollmann and Andrew Spicer, Studies in Medieval and Reformation Traditions 121 (Leiden: Brill, 2007), 49-67, especially 66-67.

${ }^{41}$ Hollstein, 38:105, no. 214.

${ }^{42}$ Although Jonathan Israel notes that Protestant refugees from the south most fervently maintained faith in this construct of Netherlandish unity, he argues that this was not the mainstream of either elite and popular opinion, to the point that "in the Dutch Golden Age the idea of a common Fatherland of seventeen provinces played scarcely any part as an inspiration and motive force in culture and politics." See Israel, The Dutch Republic, 420. Pollmann concurs, arguing that the notions of Netherlandishness evoked by northerners in this period served primarily to consolidate a particularly Dutch identity in contradistinction to the hispanized Southern Netherlanders. See Pollmann, "No Man's Land." 241-61. It is possible that the Leo Belgicusformat was simply a holdover from an earlier period of hope for Netherlandish national unity, but I would argue instead that it offers visual proof that the idea of unity still held considerable sway during the Twelve Years' Truce.

${ }^{43}$ Hollstein, 38:84-86, nos. 149-60. Although 1611-12 is the date most frequently given to these prints, Christiaan Schuckman has argued that the copper plate shown leaning on the ledge of the table of contents represents the Nieuwe Kerk of Amsterdam, which Visscher etched in 1612-13 and which served as an illustration in the 1613 edition of Guicciardini's Omnium Belgie, published in Amsterdam. This slightly later date might suggest that Visscher etched and published the Plaisante Plaetsenjust after he completed his Small Landscapecopies. See Schuckman in Luijten et al., Dawn of the Golden Age, 653 n12. For recent literature on the series, see Levesque, Journey through Landscape, 35-54, which emphasizes the series' relationship to the tradition of descriptive geography begun in the Low Countries in the sixteenth century; see Leeflang, "Dutch Landscape: The Urban View" and Gibson, Pleasant Places, particularly 85-116.

${ }^{44}$ The Small Landscapesare routinely acknowledged as the formal precedent for Visscher's Plaisante Plaetsenseries, and several scholars have discussed the connection between Visscher's copies of the earlier series and his views of Haarlem explicitly. See, for instance, Gibson, Pleasant Places, 38, 85; and Michalsky, "Nature der Nation," 344. Catherine Levesque also mentions Visscher's copies of the Small Landscapes, though she relates the Plaisante Plaetsenmore explicitly to the Large Landscapeseries, designed by Pieter Bruegel and published by Hieronymus Cock slightly before the Small Landscapes, in order to place the Plaisante Plaetsenmore convincingly within the humanist tradition of descriptive geography. See Levesque, Journey through Landscape, 17-41.

${ }^{45}$ Visscher includes more notable monuments in the Haarlem series than one finds in the Small Landscapes, including the historically significant Leper Asylum and the Huis ter Kleef, which had served as a Spanish encampment and headquarters, respectively, during the Spanish siege of Haarlem in 1572-73. In this manner, Visscher introduces a historical resonance to the Plaisante Plaetsen, figuring this landscape not only in its present prosperity and peace but also in the aftermath of the military operations of its recent past. See Levesque, Journey through Landscape, 47-48.

\section{Bibliography}

Adams, Ann Jensen. "Competing Communities in the 'Great Bog of Europe': Identity and 17th-Century Dutch Landscape." In Landscape and Power, edited by W. J. T. Mitchell, 35-76. Chicago: University of Chicago Press, 1994. 
Bakker, Boudewijn. "Levenspelgrimage of vrome wandeling? Claes Visscher en zijn serie Plaisante Plaetsen." Oud Holland 107, no. 1 (1993): 97-115. doi:10.1163/187501793X00135

- - - "'Pictores adeste!' Hieronymus Cock Recommending His Print Series." Simiolus: Netherlands Quarterly for the History of Art 33 (2007): 62-63.

Begemann, Egbert Haverkamp, and Alan Chong. "Dutch Landscape Painting and Its Associations." In The Royal Picture Gallery, Mauritshuis, edited by H. R. Hoetink, 56-67. Amsterdam: Meulenhoff/Landshoff, 1985.

Briels, J. G. C. A. Zuid-Nederlandse Immigratie 1572-1630. Haarlem: Fibula-Van Dishoeck, 1978.

Brown, Christopher. Dutch Landscape: The Early Years, Haarlem and Amsterdam 1590-1650. London: National Gallery, 1986.

Bruyn, Josua. "Toward a Scriptural Reading of Seventeenth-Century Dutch Landscape Painting." In Masters of Seventeenth-Century Landscape Painting, edited by P. C. Hutton, 84-103. Boston: Museum of Fine Arts, 1987.

van Deursen, A. T. "The Dutch Republic, 1588-1780." In History of the Low Countries, edited by J. C. H. Blom and E. Lamberts, translated by James C. Kennedy. New ed. New York and Oxford: Berghahn Books, 2006.

Diels, Ann. "Hans Collaert I." In Met passer en penseel: Brussel en het oude hertogdom Brabant in beeld, 206-10. Brussels: Dexia, 2000.

- - . The Shadow of Rubens: Print Publishing in 17th-Century Antwerp: Prints by the History Painters Abraham Van Diepenbeeck, Cornelis Schut and Erasmus Quellinus II. Turnhout, Belgium: Harvey Miller Publishers, 2009.

Doodewaard, William van. "Remonstrants, Contra-Remonstrants and the Synod of Dort (16181619): The Religious History of the Early Dutch Republic." Canadian Journal of Netherlandic Studies 28 (2007): 140-65.

Duke, Alastair. "In Defence of the Common Fatherland: Patriotism and Liberty in the Low Countries, 1555-1576." In Networks, Regions and Nations: Shaping Identities in the Low Countries, 1300-1650, edited by Robert Stein and Judith Pollmann, 217-39. Leiden: Brill, 2010.

- - - "The Elusive Netherlands: The Question of National Identity in the Early Modern Low Countries on the Eve of the Revolt." In Dissident Identities in the Early Modern Low Countries, 9-51. Farmham, England, and Burlington, Vt.: Ashgate, 2009.

Dutch, Flemish and German Drawings, auction catalogue, Christie's Amsterdam, November 30, 1987. 
van Eeghen, I. H. “De familie van de plaatsnijder Claes Jansz Visscher." Amstelodamum 77 (1990): 73-82.

Falkenburg, Reindert. "Calvinism and the Emergence of Dutch Seventeenth-Century Landscape Art: A Critical Evaluation." In Seeing Beyond the Word: Visual Arts and the Calvinist Tradition, edited by Paul Corby Finney, 343-68. Cambridge: Eerdmans, 1999.

- - - "De betekenis van het geschilderde Hollandse landschap van de zeventiende eeuw: Een beschouwing naar aanleiding van enkele recente interpretaties." Theoretische Geschiedenis 16 (1989): 131-53.

Freedberg, David. Dutch Landscape Prints of the Seventeenth Century. London: British Museum Publications, 1980.

Gibson, Walter. Pleasant Places: The Rustic Landscape from Bruegel to Ruisdael. Berkeley: University of California Press, 2000.

Hautekeete, Stefaan. "Van stad en land: Het beeld van Brabant in de vroege topografische tekenkunst." In Met passer en penseel: Brussel en het oude hertogdom Brabant in beeld, 46-57. Brussels: Dexia, 2000.

Israel, Jonathan. The Dutch Republic: Its Rise, Greatness, and Fall, 1477-1806. Oxford History of Early Modern Europe. Oxford and New York: Oxford University Press, 1995.

Kinds, Karel. Kroniek van de opstand in de Lage Landen, 1555-1609. [Netherlands]: Association Luxembourgeoise pour les Nations Unies, 1999.

Knaap, Anna. "From Low-Life to Rustic Idyll: The Peasant Genre in 17th-Century Dutch Drawings and Prints." Harvard University Art Museum Bulletin 4 (1996): 30-59.

de Kooker, H. W., and B. van Selm. Boekcultuur in de Lage Landen, 1500-1800: Bibliografie van publicaties over particulier boekenbezit in Noord-en Zuid-Nederland, verschenen voor 1991. Utrecht: HES Publishers, 1993.

Leeflang, Huigen. "Dutch Landscape: The Urban View: Haarlem and Its Environs in Literature and Art, 15th-17th Century." Nederlands Kunsthistorisch Jaarboek 48 (1997): 53-115.

- - - "Het landschap in boek en prent: Perceptie en interpretatie van vroeg zeventiende-eeuwse Nederlandse lanschapsprenten." In Nederland naar't leven: Landschapsprenten uit de Gouden Eeuw, edited by Boudewijn Bakker and Huigen Leeflang, 18-32. Zwolle: Waanders, 1993.

Levesque, Catherine. Journey through Landscape in Seventeenth-Century Holland: The Haarlem Print Series and Dutch Identity. University Park, Pa.: Pennsylvania State University Press, 1994. 
Luijten, Ger, Ariane van Suchtelen, Reinier Baarsen, Wouter Kloek, and Marijn Schapelhouman, eds. Dawn of the Golden Age: Northern Netherlandish Art, 1580-1620. Amsterdam: Rijksmuseum, 1993.

Melion, Walter. Shaping the Netherlandish Canon: Karel van Mander's Schilderboek. Chicago: University of Chicago Press, 1991.

Michalsky, Tanja. "Die Natur der Nation: Überlegungen zur 'Landschaft' als Ausdruck nationaler Identität." In Europa im 17. Jahrhundert: Ein Politischer Mythos und seine Bilder, edited by Klaus Bussmann and Elke Anna Werner, 333-54. Stuttgart: Franz Steiner Verlag, 2004.

Nora, Pierre. Realms of Memory: The Construction of the French Past. Edited by Lawrence D Kritzman. Translated by Arthur Goldhammer. 3 vols. European Perspectives. New York: Columbia University Press, 1996.

Onuf, Alexandra. "Local Terrains: The Small Landscape Prints and the Depiction of the Countryside in Early Modern Antwerp.” PhD diss., Columbia University, 2006.

-_—. "Small Landscapes in Seventeenth-Century Antwerp." Burlington Magazine 150, no. 1260 (2008): 190-93.

Orenstein, Nadine. "Marketing Prints to the Dutch Republic: Novelty and the Print Publisher." Journal of Medieval and Early Modern Studies 28, no. 1 (1998): 141-65.

Orenstein, Nadine, ed. Pieter Bruegel the Elder: Drawings and Prints. New Haven, Conn.: Yale University Press, 2001.

Orenstein, Nadine, Huigen Leeflang, Ger Luiten, and Christiaan Schuckman. "Print Publishers in the Netherlands, 1580-1620." In Ger Luijten et al., eds., Dawn of the Golden Age: Northern Netherlandish Art, 1580-1620. Amsterdam: Rijksmuseum, 1993.

Parshall, Peter. "Imago Contrafacto: Images and Facts in the Northern Renaissance." Art History 16, no. 4 (1993): 554-79.

Pollmann, Judith. “'Brabanters do fairly resemble Spaniards after all': Memory, Propaganda and Identity in the Twelve Years' Truce." In Public Opinion and Changing Identities in the Early Modern Netherlands: Essays in Honour of Alastair Duke, edited by Judith Pollmann and Andrew Spicer, 211-27. Studies in Medieval and Reformation Traditions 121. Leiden: Brill, 2007.

-_- "No Man's Land: Reinventing Netherlandish Identities, 1585-1621." In Networks, Regions and Nations: Shaping Identities in the Low Countries, 1300-1650, edited by Robert Stein and Judith Pollmann, 241-61. Leiden: Brill, 2010. doi:10.1163/ej.9789004180246.i-292.51

Raupp, H. J. “Zur Bedeutung und Symbol für die holländische Landschaftsmalerei des 17. Jahrhunderts." Jahrbuch der Staatlichen Kunstsammlungen in Baden-Württenberg 17 (1980): 
85-110.

Regan, Paul. "Cartography, Chorography and Patriotic Sentiment in the Sixteenth-Century Low Countries." In Public Opinion and Changing Identities in the Early Modern Netherlands: Essays in Honour of Alastair Duke, edited by Judith Pollmann and Andrew Spicer, 49-67. Studies in Medieval and Reformation Traditions 121. Leiden: Brill, 2007.

Roegiers, Jan, and Bart van der Herten, eds. Eenheid op Papier: De Nederlanden in Kaart van Keizer Karel tot Willem I. Leuven: Davidsfonds, 1994.

Schama, Simon. "Culture as Foreground." In Masters of Seventeenth-Century Dutch Landscape Painting, edited by Peter C. Sutton, 64-83. Boston: Museum of Fine Arts, 1987.

Sellink, Manfred. "De markt voor grafiek in Antwerpen: De zestiende en zeventiende eeuw." In Copyright Rubens: Rubens en de Grafiek, edited by Nico Van Hout, 150-55. Ghent: Ludion, 2004.

Silver, Larry. “The Importance of Being Bruegel: The Posthumous Survival of the Art of Pieter Bruegel the Elder." In Pieter Bruegel the Elder: Drawings and Prints, edited by Nadine Orenstein, 67-84. New Haven, Conn.: Yale University Press, 2001.

Simon, M. “Claes Jansz. Visscher.” PhD diss., University of Fribourg, 1958.

Sluijter, Eric Jan. “On Brabant Rubbish, Economic Competition, Artistic Rivalry, and the Growth of the Market for Paintings in the First Decades of the Seventeenth Century." Journal of Historians of Netherlandish Art 1, no. 2 (2009): www.jhna.org. (Originally published as "Over Brabantse vodden, economische concurrentie, artistieke wedijver en de groei van de markt voor schilderijen in de eerste decennia van de zeventiende eeuw," in Kunst voor de markt, edited by R. Falkenburg, J. de Jong, and B. Ramakers, Nederlands Kunsthistorisch Jaarboek 50 (1999): 112-43). doi:10.5092l jhna.2009.1.2.4

Swan, Claudia. "Ad vivum, naer het leven, from the life: Defining a Mode of Representation." Word and Image 11 (1995): 353-72.

Vloten, Johannes van. Nederlandsche geschiedzangen naar tijdsorde gerangschikt en toegelicht. Amsterdam: K. H. Schadd, 1864.

Zwollo, An. "Hans Bol, Pieter Stevens en Jacob Savery, enige kanttekeningen." Oud Holland 84, no. 4 (1969): 298-302.

\section{Recommended Citation:}

